\title{
The Effects of Different Types of Fly Ash on the Compressive Strength Properties of Briquettes
}

\author{
Özlem Çelik Sola, ${ }^{1}$ Murat Yayla, ${ }^{2}$ Barış Sayın, ${ }^{3}$ and Cengiz Duran Atiş ${ }^{4}$ \\ ${ }^{1}$ Civil Engineering Department, Engineering Faculty, Istanbul University, Avcllar Campus, Avclar, Istanbul, Turkey \\ ${ }^{2}$ Yapi Insaat Ltd. Co., Istanbul, Turkey \\ ${ }^{3}$ Building and Technical Office, Istanbul University, Beyazıt Campus, Istanbul, Turkey \\ ${ }^{4}$ Civil Engineering Department, Engineering and Architecture Faculty, Abdullah Gul University, Kayseri, Turkey
}

Correspondence should be addressed to Özlem Çelik Sola, celik@istanbul.edu.tr

Received 10 May 2011; Accepted 9 July 2011

Academic Editor: Kin Ho Lo

Copyright (๑) 2011 Özlem Çelik Sola et al. This is an open access article distributed under the Creative Commons Attribution License, which permits unrestricted use, distribution, and reproduction in any medium, provided the original work is properly cited.

The aim of this study is to evaluate the effect of the different types of fly ash on the compressive strength properties of sintered briquettes. Thermal gravimetric (TG) analysis was carried out. The chemical composition and physical properties of the materials used were determined. Particle size distribution and microstructure elemental analyses of the materials used were carried out by a particle size analyzer (Mastersizer) and a scanning electron microscope (SEM-EDS). Following the characterization of the materials, briquettes were prepared by sintering at different temperatures. Compressive strength test results of the briquette samples indicated that briquettes with a compressive strength value of $47.45 \mathrm{~N} / \mathrm{mm}^{2}$ can be produced. The results obtained exceed the Turkish standard (TS EN 771-1) requirements $\left(9.8-23.54 \mathrm{~N} / \mathrm{mm}^{2}\right.$ ). SEM-EDS results showed that briquette samples made with Tunçbilek (T) fly ash had a higher percentage of the glassy phase than the other briquette samples. Due to this microstructure, it results in higher compressive strength value.

\section{Introduction}

As an industrial waste, fly ash presents some environmental and storage problems; however, it has been used widely as an excellent mineral additive in the construction industry $[1,2]$. The use of fly ash prevents environmental pollution, and it contributes to a reduced need for natural resources. Fly ash is available in different types, such as $\mathrm{C}$ and $\mathrm{F}$. The $\mathrm{F}$ type has a low $\mathrm{Ca}$ content, and its content of $\mathrm{SiO}_{2}+\mathrm{Fe}_{2} \mathrm{O}_{3}$ $+\mathrm{Al}_{2} \mathrm{O}_{3}$ is greater than 70 (ASTM C 618) [3]. There are many studies investigating fly ash and its use as an additive in cement mortars $[4,5]$. Fly ash is also used as an additive in the production of briquettes [6-11]. This study presents comprehensive details about the utilization of different types of fly ash that were collected from different thermal power plants (Çayırhan, Orhaneli, Seyitömer, and Tunçbilek) in Turkey and that were used to produce briquettes that have high compressive strength values.

\section{Materials and Methods}

\subsection{Properties of Materials Used}

2.1.1. Soil. The soil was obtained from the Boyabat Brick Factory in Turkey. Its specific surface area was $0.7502 \mathrm{~m}^{2} / \mathrm{g}$, and its chemical properties are given in Table 1. It had a high $\mathrm{SiO}_{2}$ content (51.21\%).

2.1.2. Fly Ash. Four samples of fly ash were collected from the Çayırhan (C), Orhaneli (OE), Seyitömer (SO), and Tunçbilek ( $\mathrm{T})$ thermal power plants in Turkey, which are recycling materials for evaluation as additive materials in the building sector. Their specific surface areas are 0.5957, $0.8731,0.4420$, and $1.2769 \mathrm{~m}^{2} / \mathrm{g}$, respectively. The chemical analysis results of the fly ashes are given in Table 1 . According to ASTM 618, the $\mathrm{SiO}_{2}+\mathrm{Al}_{2} \mathrm{O}_{3}+\mathrm{Fe}_{2} \mathrm{O}_{3}$ values indicated that 
TABLE 1: The chemical composition (\%w/w) of the materials used.

\begin{tabular}{lccccc}
\hline Constituents (\%) & Soil & $\mathrm{C}$ & $\mathrm{OE}$ & $\mathrm{SO}$ & $\mathrm{T}$ \\
\hline $\mathrm{SiO}_{2}$ & 51.21 & 44.05 & 43.18 & 53.32 & 58.36 \\
$\mathrm{Al}_{2} \mathrm{O}_{3}$ & 12.59 & 11.57 & 19.36 & 20.16 & 22.17 \\
$\mathrm{Fe}_{2} \mathrm{O}_{3}$ & 2.66 & 8.81 & 7.71 & 10.50 & 7.09 \\
$\mathrm{CaO}$ & 7.04 & 14.19 & 17.84 & 4.40 & 2.61 \\
$\mathrm{MgO}$ & 3.31 & 4.97 & 2.80 & 4.50 & 2.46 \\
$\mathrm{~K}_{2} \mathrm{O}$ & 1.70 & 1.80 & 1.64 & 2.98 & 2.27 \\
$\mathrm{Na}_{2} \mathrm{O}$ & 1.52 & 3.59 & 0.36 & 0.51 & 0.71 \\
$\mathrm{SO}_{3}$ & 5.57 & 10.34 & 2.53 & 1.04 & 0.34 \\
$\mathrm{KK}$ & 12.00 & 1.39 & 4.00 & 1.65 & 3.35 \\
$\mathrm{~F} \mathrm{CaO}^{-}$ & 0.07 & 0.14 & 0.31 & - & 0.01 \\
$\mathrm{Cl}^{-}$ & 0.0085 & - & - & - & - \\
\hline
\end{tabular}

TABLe 2: Content of the soil sample.

\begin{tabular}{lc}
\hline Content & $\% \mathrm{w} / \mathrm{w}$ \\
\hline Gravel & 0.0 \\
Sand & 24.1 \\
Silt & 63.4 \\
Clay & 12.5 \\
\hline
\end{tabular}

the fly ash sample obtained from the (C) thermal power plant should be classified as type $\mathrm{C}$ and the (OE), (SO), and (T) fly ash samples should be classified as type $\mathrm{F}$.

2.1.3. Experimental Program. In order to prepare the briquette specimens from the materials, characterization experiments were carried out. A physical analysis of the soil was performed to determine the percentage of sand and gravel present. In addition to the physical analysis, a hydrometer analysis was applied to the mass of the soil that passed through sieve No. 200 in order to separate the silt and clay materials. Tests of the consistency limits of the soilthe plastic limit, the liquid limit, and the plasticity index (PI) - were conducted. In order to determine the thermal behavior of the soil, a TG analysis was carried out with a TGA-50. The particle size distribution of the materials was measured by the Mastersizer- $x$ technique (Malvern, MS-X 1995 model). In order to describe the microstructure and to conduct an elemental analysis of the materials and briquettes, the SEM-EDS technique (JSM-5910LV, EDS Model: OxfordInca-7274) was used. The compressive strength results were explained by using the results obtained from these analyses.

2.1.4. Preparation and Testing of Briquettes. Following the characterization tests, different mixtures were prepared from fly ash samples. Fly ash was added to the soil in ratios of 5\% and $10 \%$. Each mixture was treated with $6 \%$ water to provide sufficient plasticity. At the end of this procedure, the mixtures were squeezed at $200 \mathrm{kgf} / \mathrm{cm}^{2}$, and the samples were molded
TABLE 3: Test of consistency limits of the soil sample.

\begin{tabular}{lc}
\hline Limits & $\%$ \\
\hline Liquid & 37.5 \\
Plastic & 23.4 \\
Plasticity index & 14.1 \\
\hline
\end{tabular}

TABLe 4: Granulometric data for the materials used in experiments and their size fractions.

\begin{tabular}{lccc}
\hline & \multicolumn{3}{c}{ Percentages \% of particles with diameter } \\
Materials & $d_{(0.10)}(\mu \mathrm{m})$ & $d_{(0.50)}(\mu \mathrm{m})$ & $d_{(0.90)}(\mu \mathrm{m})$ \\
\hline $\mathrm{S}$ & 2.83 & 17.44 & 73.41 \\
$\mathrm{C}$ & 3.70 & 27.23 & 129.95 \\
$\mathrm{OE}$ & 3.43 & 21.18 & 77.71 \\
$\mathrm{SO}$ & 6.16 & 29.76 & 96.86 \\
$\mathrm{~T}$ & 1.99 & 13.76 & 52.39 \\
\hline
\end{tabular}

for sintering. Before sintering, the moisture in the mixtures was evaporated in an oven at $105^{\circ} \mathrm{C}$. The remolded mixtures had dimensions of $3.6 \times 3.6 \mathrm{~cm}^{2}$, and they were sintered at 850,900 , and $950^{\circ} \mathrm{C}$ in the laboratory oven. After the oven had reached the required temperature, the briquettes were removed from the oven. The briquettes produced with this process were tested for compressive strength according to the Turkish standards (TS EN 771-1) [12].

\section{Results and Discussion}

\subsection{Characterization of the Materials}

3.1.1. Hydrometer Analysis. A hydrometer analysis was carried out to obtain the soil content, which was found to be $24.1 \%$ sand, $63.4 \%$ silt, and $12.5 \%$ clay. The findings are listed in Table 2. The results of the tests of the consistency limits of the soil are given in Table 3: a 37.5\% liquid limit, a $23.4 \%$ plastic limit, and a $14.1 \%$ plasticity index. From the test results, it can be concluded that the soil is suitable for brick production according to the American Association of State Highway and Transportation Officials (AASHTO).

3.1.2. Particle Size Distribution. The Mastersizer-x technique was used for measuring the particle size distribution. Granulometric data for the S showed that the $d_{(90)}$ and $d_{(50)}$ values were 73.41 and $17.44 \mu \mathrm{m}$. Granulometric data for the size fractions of the $\mathrm{C}, \mathrm{OE}, \mathrm{SO}$, and $\mathrm{T}$ fly ash is displayed in Table 4; the $d_{(90)}$ and $d_{(50)}$ values were 129.95 and 27.23 , 77.71 , and $21.18,96.86$, and 29.76 and 52.39 and $13.76 \mu \mathrm{m}$, respectively. The particle size ranged from $3 \mu \mathrm{m}$ to well over $129 \mu \mathrm{m}$ for the materials. It can be observed that there are significant differences in the particle size distributions of the two samples of $\mathrm{C}$ and $\mathrm{T}$ for $d_{(90)}: 129.95$ and $52.39 \mu \mathrm{m}$, respectively. It can also be observed from the granulometric data that $\mathrm{T}$ was the finest fly ash. 


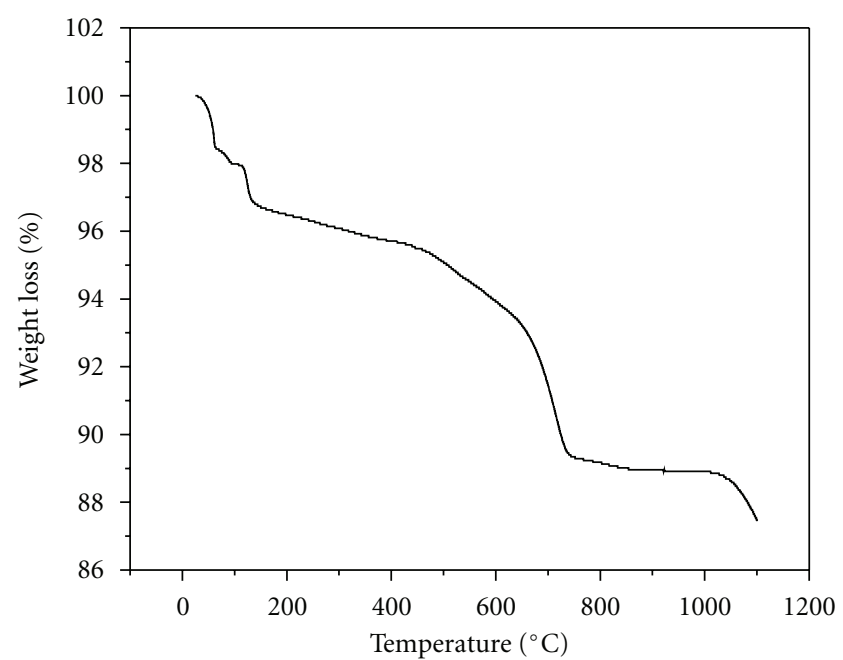

FIGURE 1: TG analysis of the soil sample.

3.1.3. Thermogravimetric (TG) Analysis. In order to obtain the thermal behavior of the soil, a TG analysis was carried out. A 13\% weight loss was found. The moisture and water loss of the soil were $4 \%$ up to $200^{\circ} \mathrm{C}$. Decomposition started and the water loss of the soil increased to $7 \%$ between 200 and $800^{\circ} \mathrm{C}$. Figure 1 shows that above $800^{\circ} \mathrm{C}$, decomposition continued, but the curve is not very sharp. Therefore, the temperature range from 850 to $950^{\circ} \mathrm{C}$ was chosen for sintering.

3.1.4. Morphological and Elemental Analyses. Morphological and elemental analyses were conducted using SEM-EDS. Figure 2 shows that fly ash samples are spherical in shape, whereas the soil sample is amorphous. The T fly ash sample has a finer particle size than the $\mathrm{C}$ fly ash sample, and the elemental analysis shows that the $\mathrm{C}$ fly ash sample has more Ca content than the $\mathrm{T}$ fly ash sample (Table 3 ). The $\mathrm{C}$ fly ash is $\mathrm{C}$ type, and the $\mathrm{T}$ fly ash is $\mathrm{F}$ type [5]. In addition to the morphological analyses performed to obtain an elemental analysis of the materials, four points $(\mathrm{P})$ were chosen on the SEM photographs, and they were analyzed. The analysis results are shown in Table 5.

\subsection{Compressive Strength Values of the Produced Briquettes}

3.2.1. Mixing Ratios and Compressive Strength Values of the Produced Briquettes. After the sintering process, compressive strength tests of the briquettes were performed according to the Turkish standard (TS EN 771-1). It was concluded that briquettes with a compressive strength value of $47.45 \mathrm{~N} / \mathrm{mm}^{2}$ can be produced at $950^{\circ} \mathrm{C}$. This result was obtained from the briquette that was prepared with $5 \% \mathrm{~T}$ fly ash. This is the best compressive strength result obtained for the samples that were prepared. This compressive strength result is a very high value; the Turkish standard (TS EN 771-1) only requires 9.8-23.54 N/mm ${ }^{2}$. When the briquettes made with $\mathrm{T}$ fly ash were compared with the others, the compressive strength of the $\mathrm{T}$ briquettes was higher than that of the others at the same temperatures. The compressive strength results for the briquettes are shown in Table 6. The compressive strength of the briquettes changed with the different types of fly ash.

3.2.2. SEM-EDS Analysis of the Briquettes after the Compressive Strength Tests. After the compressive strength tests, morphological and elemental analyses were applied to the samples by using SEM-EDS. There are three groups of mixtures. The first group included mixtures with 5\% fly ash, the second group included those with $10 \%$ fly ash, and the third group included mixtures with $20 \%$ fly ash. Samples were chosen from the first group (b, e) and the third group (1). The samples b and e have 5\% fly ash; they contain different types of fly ash, and 1 includes two samples with $10 \%$ fly ash, with different types of fly ashes (C and $\mathrm{OE}$ ). No samples were chosen from the second group because their compressive strength results were similar to those of the first group. The selected samples have the best mechanical strengths in their respective groups.

It can be observed in Figure 3 that there are distinct differences between sample e and the others. Primarily, a quartz $\left(\mathrm{SiO}_{2}\right)$ phase was formed, and this can be seen in Figure 3 . This is comparable with point 1 of Table 7 . There are different phases shown in Figure 3. These phases are anhydrite $\left(\mathrm{CaSO}_{4}\right)$ in trace ratios, gehlenite $\left(2 \mathrm{CaO} \cdot \mathrm{Al} 2 \mathrm{O} 3 \cdot \mathrm{SiO}_{2}\right)$, potassium aluminum silicate $\left(\mathrm{K}_{2} \mathrm{O} \cdot \mathrm{Al}_{2} \mathrm{O}_{3} \cdot 4 \mathrm{SiO}_{2}\right)$, hematite $\left(\mathrm{Fe}_{2} \mathrm{O}_{3}\right)$, and aluminum silicate $\left(3 \mathrm{Al}_{2} \mathrm{O}_{3} \cdot 2 \mathrm{SiO}_{2}\right)$. Here, the phases that affect the compressive strength properties are quartz, gehlenite, and potassium aluminum silicate. These phases are all proportional in Table 7.

\section{Conclusions}

The following conclusions can be drawn from the experimental results.

(i) Briquettes can be manufactured with different types of fly ash.

(ii) The briquettes sintered at $950^{\circ} \mathrm{C}$ had better compressive strength results than those sintered at 900 and $850^{\circ} \mathrm{C}$.

(iii) When the amount of fly ash added was increased from $5 \%$ to $10 \%$, the compressive strength decreased, but the compressive strength of all of the briquettes was higher than $9.8 \mathrm{~N} / \mathrm{mm}^{2}$.

(iv) The briquette created with $5 \% \mathrm{~T}$ fly ash had better mechanical strength than did those prepared using other materials. The mechanical strength of this briquette was very high $\left(47.45 \mathrm{~N} / \mathrm{mm}^{2}\right)$, and when compared with the standard value $\left(9.8-23.54 \mathrm{~N} / \mathrm{mm}^{2}\right)$, it is remarkable. Therefore, stronger construction could be designed with these briquettes.

(v) Fly ash not only provides better mechanical strength for building materials but also contributes to decreasing environmental pollution, production costs, and the use of natural resources. 


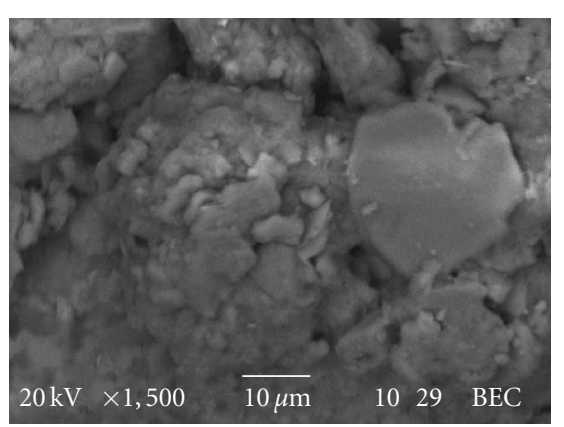

(a)

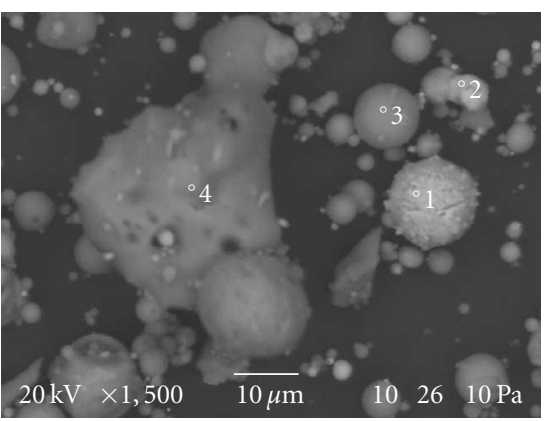

(b)

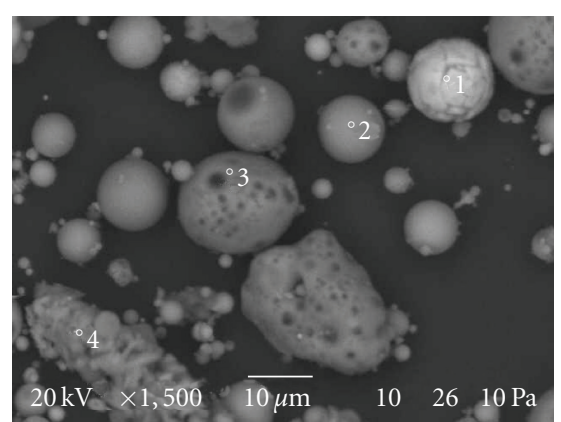

(c)

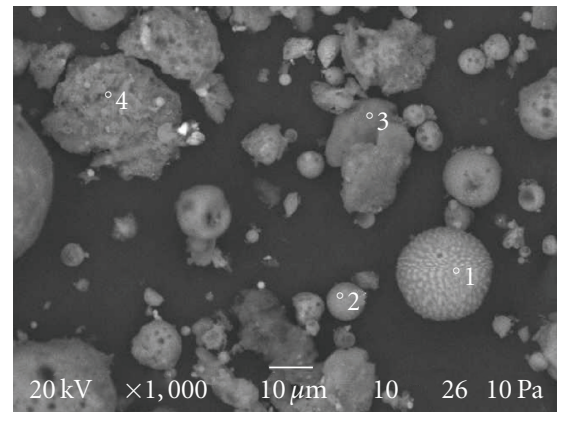

(d)

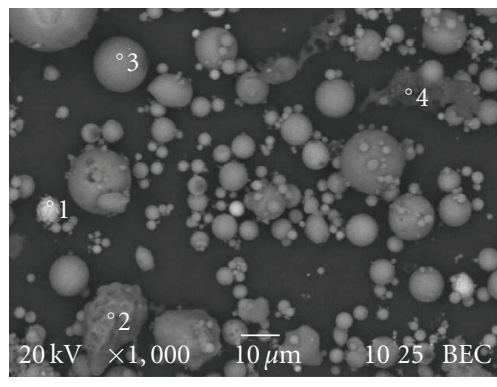

(e)

FIgURE 2: SEM micrographs of fly ashes (a) Soil $\times 1500$ (b) C $\times 1500$ (c) $\mathrm{OE} \times 1500$ (d) SO $\times 1000$ (e) $\mathrm{T} \times 1000$.

TABLE 5: SEM-EDS elemental analyses of materials.

\begin{tabular}{|c|c|c|c|c|c|c|c|c|c|c|c|c|c|}
\hline \multicolumn{14}{|c|}{ Elemental analysis } \\
\hline & $\mathrm{C}$ & $\mathrm{O}$ & $\mathrm{Na}$ & $\mathrm{Mg}$ & $\mathrm{Al}$ & $\mathrm{Si}$ & $\mathrm{P}$ & $S$ & $\mathrm{~K}$ & $\mathrm{Ca}$ & $\mathrm{Ti}$ & $\mathrm{Fe}$ & Total \\
\hline \multicolumn{14}{|c|}{$S$} \\
\hline $\mathrm{P} 1$ & & 54.44 & 0.85 & 2.72 & 8.41 & 18.43 & & 2.54 & 2.00 & 4.63 & 0.45 & 5.52 & 100 \\
\hline \multicolumn{14}{|c|}{$\mathrm{C}$} \\
\hline P1 & 13.15 & 37.14 & & & 1.65 & 3.10 & & 0.55 & & 1.69 & & 42.73 & 100 \\
\hline $\mathrm{P} 2$ & 8.92 & 40.93 & & 3.30 & 2.13 & 3.95 & & 1.34 & & 7.56 & & 31.87 & 100 \\
\hline P3 & 12.64 & 49.21 & 0.85 & 6.43 & 5.94 & 12.57 & & 0.59 & & 9.04 & 1.17 & 1.56 & 100 \\
\hline $\mathrm{P} 4$ & 13.23 & 47.94 & & 5.04 & 2.63 & 13.28 & 0.78 & 0.65 & 0.34 & 11.52 & 0.64 & 3.95 & 100 \\
\hline \multicolumn{14}{|c|}{$\mathrm{OE}$} \\
\hline $\mathrm{P} 1$ & 15.32 & 35.68 & & & 2.99 & 2.87 & & & & 1.34 & & 41.81 & 100 \\
\hline $\mathrm{P} 2$ & & 51.95 & & 2.01 & 11.36 & 18.78 & & & 1.30 & 9.54 & & 5.06 & 100 \\
\hline P3 & 25.25 & 43.82 & 0.68 & 0.61 & 11.98 & 13.72 & & & 0.81 & 1.64 & & 1.49 & 100 \\
\hline $\mathrm{P} 4$ & 17.76 & 49.20 & & 0.61 & 2.37 & 2.17 & & 0.57 & & 26.40 & & 0.92 & 100 \\
\hline \multicolumn{14}{|c|}{$\mathrm{SO}$} \\
\hline P1 & 21.88 & 37.14 & & 1.44 & 3.43 & 10.66 & & & 0.78 & 1.32 & & 23.34 & 100 \\
\hline $\mathrm{P} 2$ & 18.73 & 47.96 & & 2.01 & 7.95 & 15.30 & & & 1.72 & 3.38 & & 2.95 & 100 \\
\hline P3 & 15.70 & 53.95 & & 0.74 & 2.76 & 24.03 & & & 0.73 & 0.43 & & 1.67 & 100 \\
\hline $\mathrm{P} 4$ & 15.08 & 50.62 & & 0.77 & 10.37 & 20.25 & & & 1.29 & & & 1.60 & 100 \\
\hline \multicolumn{14}{|c|}{$\mathrm{T}$} \\
\hline $\mathrm{P} 1$ & 8.05 & 34.88 & & & 2.05 & 2.49 & & & & 0.65 & & 51.88 & 100 \\
\hline P2 & 16.32 & 50.96 & & & 0.84 & 31.89 & & & & & & & 100 \\
\hline P3 & & 52.17 & 3.08 & & 10.37 & 31.35 & & & 1.79 & & & 1.25 & 100 \\
\hline $\mathrm{P} 4$ & 74.46 & 22.39 & & & 1.15 & 2.00 & & & & & & & 100 \\
\hline
\end{tabular}




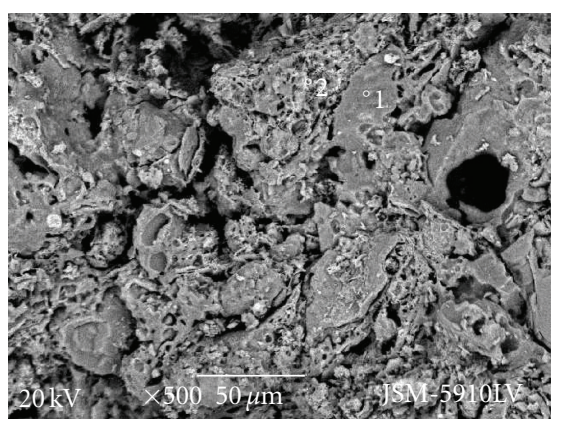

(a)

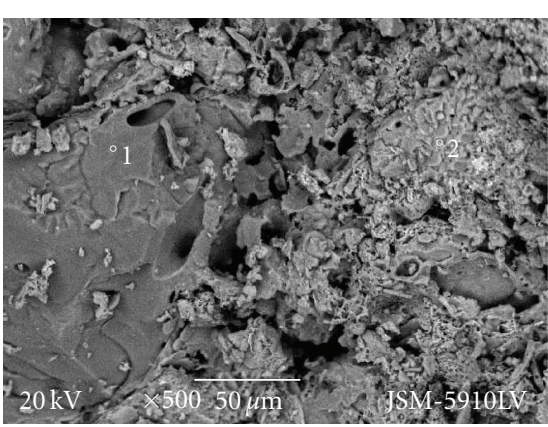

(b)

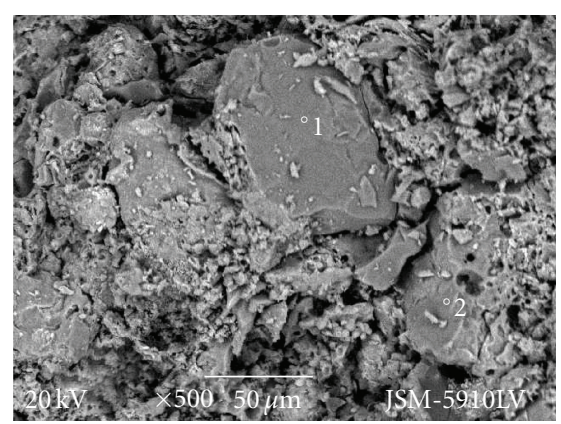

(c)

Figure 3: SEM micrographs of briquettes $(\mathrm{a}) \mathrm{b} \times 500$ (b) $\mathrm{e} \times 500$ (c) $1 \times 500$.

TABLE 6: Mixing ratios of the materials and average compressive strength values of briquettes.

\begin{tabular}{|c|c|c|c|c|}
\hline \multirow{2}{*}{ Sample code } & \multirow{2}{*}{ Mixing ratios } & \multicolumn{3}{|c|}{ Compressive strength values $\left(\mathrm{N} / \mathrm{mm}^{2}\right)$} \\
\hline & & $850^{\circ} \mathrm{C}$ & $900^{\circ} \mathrm{C}$ & $950^{\circ} \mathrm{C}$ \\
\hline b & $95 \% S+5 \% C$ & 30.8 & 38.6 & 41.4 \\
\hline c & $95 \% \mathrm{~S}+5 \% \mathrm{OE}$ & 30.8 & 38.7 & 40.7 \\
\hline $\mathrm{d}$ & $95 \% \mathrm{~S}+5 \% \mathrm{SO}$ & 26.7 & 32.7 & 34.4 \\
\hline $\mathrm{e}$ & $95 \% \mathrm{~S}+5 \% \mathrm{~TB}$ & 35.0 & 44.8 & 47.5 \\
\hline g & $90 \% S+10 \% C$ & 14.9 & 29.2 & 36.8 \\
\hline $\mathrm{h}$ & $90 \% \mathrm{~S}+10 \% \mathrm{OE}$ & 22.5 & 27.9 & 31.2 \\
\hline $\mathrm{i}$ & $90 \% \mathrm{~S}+10 \% \mathrm{SO}$ & 11.8 & 26.5 & 31.0 \\
\hline $\mathrm{j}$ & $90 \% \mathrm{~S}+10 \% \mathrm{~T}$ & 33.4 & 42.8 & 43.9 \\
\hline 1 & $80 \% \mathrm{~S}+10 \% \mathrm{C}+10 \% \mathrm{OE}$ & 15.5 & 31.7 & 38.2 \\
\hline $\mathrm{m}$ & $80 \% \mathrm{~S}+10 \% \mathrm{SO}+10 \% \mathrm{~T}$ & 17.2 & 25.0 & 27.1 \\
\hline
\end{tabular}

TABLE 7: SEM-EDS elemental analyses of briquettes (wt $\%$ ).

\begin{tabular}{|c|c|c|c|c|c|c|c|c|c|c|c|c|}
\hline \multicolumn{13}{|c|}{ Elemental analysis } \\
\hline & $\mathrm{O}$ & $\mathrm{Na}$ & $\mathrm{Mg}$ & $\mathrm{Al}$ & $\mathrm{Si}$ & $\mathrm{P}$ & $S$ & K & $\mathrm{Ca}$ & $\mathrm{Ti}$ & $\mathrm{Fe}$ & Total \\
\hline \multicolumn{13}{|c|}{$\mathrm{b}$} \\
\hline P1 & 50.91 & 3.36 & & 8.72 & 30.11 & & & 6.90 & & & & 100 \\
\hline $\mathrm{P} 2$ & 49.92 & 1.70 & 3.53 & 8.57 & 21.10 & & & 1.14 & 8.68 & & 5.36 & 100 \\
\hline \multicolumn{13}{|c|}{$\mathrm{e}$} \\
\hline P1 & 56.58 & & & & 43.42 & & & & & & & 100 \\
\hline $\mathrm{P} 2$ & 40.13 & 1.44 & 1.99 & 4.96 & 17.09 & & 1.95 & 1.03 & 16.86 & & 14.55 & 100 \\
\hline \multicolumn{13}{|c|}{1} \\
\hline P1 & 49.40 & \multirow{3}{*}{2.21} & & & 50.60 & & & \multirow{3}{*}{7.22} & & & & 100 \\
\hline P2 & 45.73 & & 1.35 & 8.96 & 31.67 & & & & 1.19 & & 1.68 & 100 \\
\hline P3 & 50.71 & & 2.83 & 8.15 & 20.67 & & & & 10.15 & & 7.50 & 100 \\
\hline
\end{tabular}

(vi) The compressive strength results of the briquettes changed with the fly ash properties.

(vii) It was proven that all of the fly ash samples used in the experiments were suitable for use in briquette production.

\section{Acknowledgments}

The authors would like to thank Istanbul Asphalt Factories Head of Production Zafer Sola for helping. This work was supported by the Scientific Research Projects Coordination Unit of Istanbul University, Project number UDP4547/13112009.

\section{References}

[1] F. Tutunlu and U. Atalay, "Utilization of fly ash in manufacturing of building bricks," in International Ash Utilization Symposium, Center for Applied Energy Research, Salt Lake City, Utah, USA, 2001. 
[2] O. Ozdemir, B. Erhan, and M. S. Celik, "Separation of pozzolanic material from lignitic fly ash of Tuncbilek power station," in International Ash Utilization Symposium, Center for Applied Energy Research, Salt Lake City, Utah, USA, 2001.

[3] ASTM standard, ASTM C 618, "Fly ash for use as mineral admixture in Portland cement concrete".

[4] Ö. Çelik, E. Damc1, and S. Pişkin, "Characterization of fly ash and it effects on the compressive strength properties of Portland cement," Indian Journal of Engineering \& Materials Sciences, vol. 15, no. 5, pp. 433-440, 2008.

[5] O. Celik, Utilization of Industrial Wastes in Building Sectors, Ph.D. thesis, Ylldız Technical University, 2004.

[6] L. Xu, W. Guo, T. Wang, and N. Yang, "Study on fired bricks with replacing clay by fly ash in high volume ratio," Construction and Building Materials, vol. 19, no. 3, pp. 243247, 2005.

[7] M. Dondi, G. Ercolani, G. Guarini, and M. Raimondo, "Orimulsión fly ash in clay bricks-part 1: composition and thermal behaviour of ash," Journal of the European Ceramic Society, vol. 22, no. 11, pp. 1729-1735, 2002.

[8] M. Dondi, G. Guarini, M. Raimondo, and I. Venturi, "Orimulsión fly ash in clay bricks_part 2: technological behaviour of clay/ash mixtures," Journal of the European Ceramic Society, vol. 22, no. 11, pp. 1737-1747, 2002.

[9] Z. Haiying, Z. Youcai, and Q. Jingyu, "Utilization of municipal solid waste incineration (MSWI) fly ash in ceramic brick: product characterization and environmental toxicity," Waste Management, vol. 31, no. 2, pp. 331-341, 2011.

[10] T. Takegawa, "Manufacture of bricks from fly ashes," Fuel and Energy Abstracts, 37-3, Chapter 96/03074, 1996.

[11] G. Cultrone and E. Sebastián, "Fly ash addition in clayey materials to improve the quality of solid bricks," Construction and Building Materials, vol. 23, no. 2, pp. 1178-1184, 2009.

[12] Turkish Standards EN 771-1, "Specification for masonry units-part 1: clay masonry units," Turkish Standards Institute, Ankara, Turkey, 2005. 

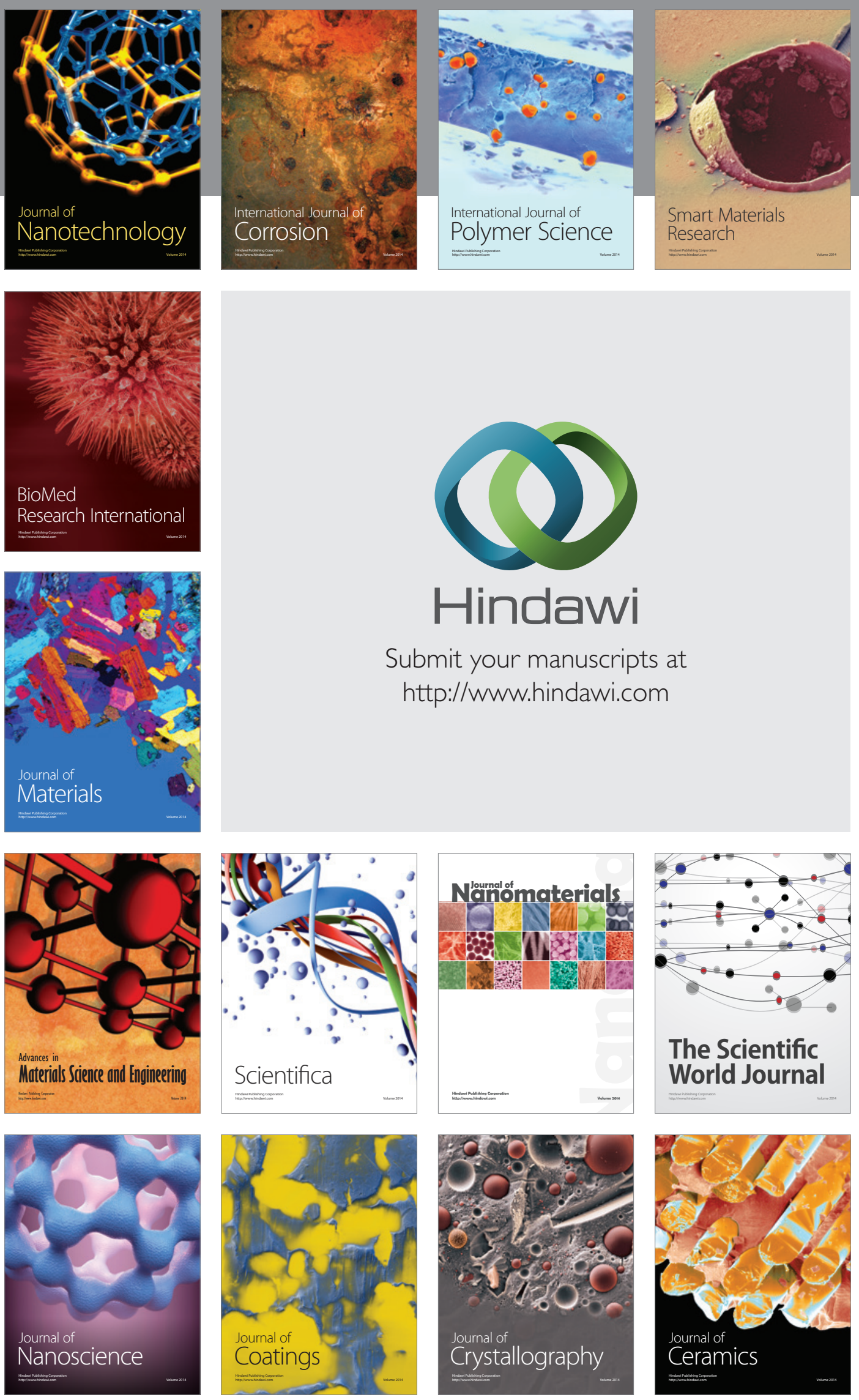

The Scientific World Journal

Submit your manuscripts at

http://www.hindawi.com

\section{World Journal}

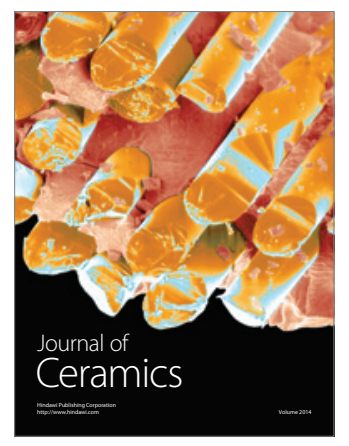

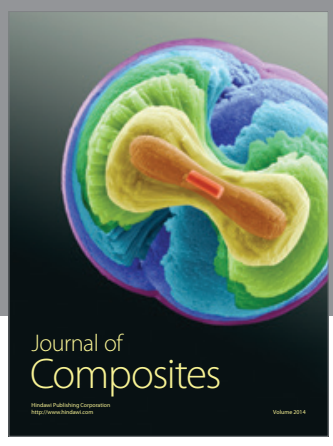
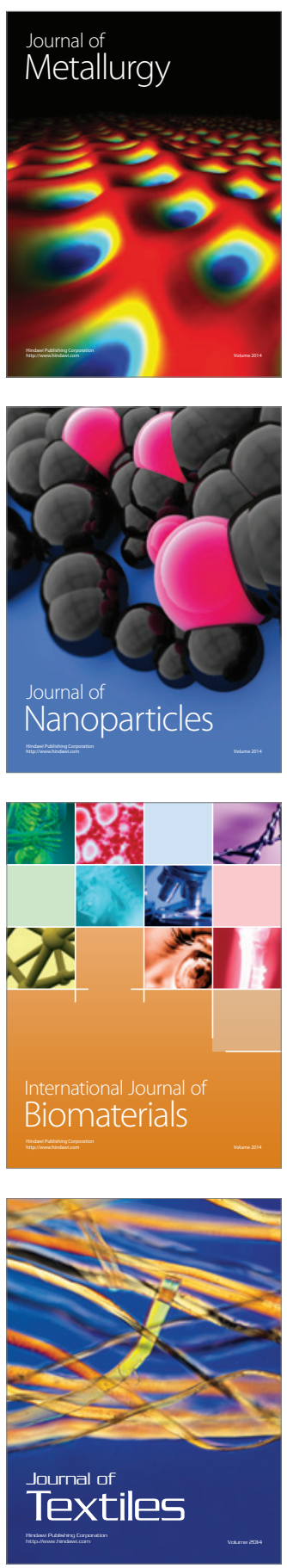